Governing the UK in the 1990 s 


\title{
Governing the UK in the 1990s
}

\author{
Edited by \\ Robert Pyper \\ and \\ Lynton Robins
}

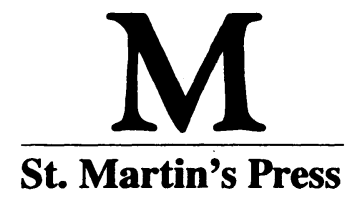


Selection, editorial matter, Introduction and Conclusion ( $)$ Robert Pyper and Lynton Robins 1995

Individual chapters (in order) $\odot$ Martin Burch, Kevin Theakston, Tony Butcher, Philip Norton, Michael Rush, Stephen Ingle, Kenneth Newton, Trevor Salman, Roger Levy, David Wilson, Clive Gray 1995

All rights reserved. No reproduction, copy or transmission of this publication may be made without written permission.

No paragraph of this publication may be reproduced, copied or transmitted save with written permission or in accordance with the provisions of the Copyright, Designs and Patents Act 1988, or under the terms of any licence permitting limited copying issued by the Copyright Licensing Agency, 90 Tottenham Court Road, London W1P 9HE.

Any person who does any unauthorised act in relation to this publication may be liable to criminal prosecution and civil claims for damages.

First published in Great Britain 1995 by

MACMILLAN PRESS LTD

Houndmills, Basingstoke, Hampshire RG21 2XS

and London

Companies and representatives

throughout the world

A catalogue record for this book is available from the British Library.

ISBN 978-0-333-58432-3

ISBN 978-1-349-23899-6 (eBook)

DOI 10.1007/978-1-349-23899-6

$\begin{array}{llllllllll}10 & 9 & 8 & 7 & 6 & 5 & 4 & 3 & 2 & 1\end{array}$

$\begin{array}{llllllllll}04 & 03 & 02 & 01 & 00 & 99 & 98 & 97 & 96 & 95\end{array}$

First published in the United States of America 1995 by

Scholarly and Reference Division,

ST. MARTIN'S PRESS, INC.,

175 Fifth Avenue,

New York, N.Y. 10010

Library of Congress Cataloging-in-Publication Data applied for 
For Anna Pyper, Robert Pyper (Senior), and Barbara Joan Robins 


\section{Contents}

List of Tables and Figures

xi

Abbreviations

Notes on the Contributors

xiv

Preface

xvii

Acknowledgements

xviii

Introduction: The Nature and Challenge of Governing in the 1990s Robert Pyper and Lynton Robins 1

How to Govern? The Dilemma of the 1990s 3

The Policy Process: Putting Government in Context 5

The Book $\quad 8$

References $\quad 12$

\section{PART I THE CENTRAL EXECUTIVE}

1 Prime Minister and Cabinet: An Executive in Transition? Martin Burch 15

The Scope and Structure of the Cabinet System 18

The Cabinet and its Committees - The Decline of the

Forum of Collective Government 20

The Central Institutions Enhanced 25

The Departments: Independence and Coordination 33

Conclusion: Possibilities for the 1990s 37

References $\quad 40$

2 Ministers and Civil Servants Kevin Theakston 43

Four Models $\quad 46$

What's Going on in Whitehall? 51

Conclusion: The Need to Widen the Focus 56

References $\quad 59$

3 A New Civil Service? The Next Steps Agencies Tony Butcher 61

The First Steps: From Fulton to Thatcher 62 
The First Steps: The Thatcher Years 63

The Ibbs Report 64

The Next Steps Programme 67

Next Steps Agencies at Work $\quad 72$

Agencies and Accountability $\quad 74$

A New Civil Service? $\quad 76$

Beyond the Next Steps: Market Testing 77

References $\quad 80$

\section{PART II PARLIAMENT AND PARTIES}

4 Parliament's Changing Role Philip Norton 85

Parliament 1945-70 86

A Changing Institution $\quad 88$

Why? $\quad 95$

With What Effect?

The Future? 101

References $\quad 104$

5 Parliamentary Scrutiny Michael Rush 108

Ministerial Responsibility and Parliamentary Scrutiny 108

The Means of Parliamentary Scrutiny 109

The House of Lords and Parliamentary Scrutiny 115

Select Committees and Parliamentary Scrutiny $\quad 117$

The Departmental Select Committees 121

Parliamentary Scrutiny: An Overview 126

$\begin{array}{ll}\text { References } & 129\end{array}$

6 The Political Parties Stephen Ingle 131

The Party System: Some Deficiencies 131

The Conservative Party 134

The Labour Party 140

The Liberal Democrats $\quad 148$

Nationalists $\quad 148$

References $\quad 151$ 


\section{PART III BEYOND WHITEHALL AND WESTMINSTER}

7 The Mass Media: Fourth Estate or Fifth Column?

Kenneth Newton

Ownership and Control of the Mass Media 156

Systematic Political Bias?

The Impact of the Media

Conclusion

References

8 The European Union Dimension Trevor Salmon 177

Pre-Entry Hesitation $\quad 177$

Hesitant Initial Membership 178

The Conservative Government's Policy Towards Europe 1979-90

The Major Government and European Integration

Impact of Membership Upon British Government

Impact of Membership Upon the British Parliament

Conclusion

References

9 Governing Scotland, Wales and Northern Ireland

Roger Levy

The Social and Political Fabric

Territorial Management by Central Government

Legislative Devolution?

References

10 Elected Local Government and Central-Local Relations David Wilson

An 'Enabling Context'

Service Provision

Compulsory Competitive Tendering

Party Politics

236

Structural Change

Internal Management

Finance 
x Contents

Analysing Recent Developments in

Central-Local Relations 244

The Framework of Central-Local Relations 248

Conclusion $\quad 250$

References 251

11 The Other Governments of Britain Clive Gray 254 Sub-National Government in Britain 254

The Dimensions of SNG 257

The Changing System: 1979-94 258

The Reform Tendency 265

The Shape of Things to Come? 267

Conclusion $\quad 274$

References $\quad 275$

Conclusion: Agendas for Reform Robert Pyper and

Lynton Robins $\quad 277$

Major's Initiatives $\quad 279$

Why Reform? $\quad 280$

The Reformers 283

Prospects 286

References $\quad 287$

$\begin{array}{ll}\text { Index } & 289\end{array}$ 


\section{List of Tables and Figures}

\section{Tables}

3.1 The Top Ten Next Steps Agencies, $1993 \quad 69$

5.1 Division of Time on the Floor of the House of Commons, 1985-86

5.2 Select Committee Activity, 1956-92

5.3 Numbers of Meetings and Reports Presented by Departmental Select Committees, 1979-92

5.4 Government Responses to Recommendations by Departmental Select Committees

8.1 The British 1975 Referendum 179

9.1 Unemployment Rates, 1981-91 205

9.2 Average Earnings, GDP and Public Spending Per Capita 206

9.3 Party Support in England, Wales, Scotland and Northern Ireland, 1987 and 1992 General Elections 207

9.4 Functional Involvement of the Territorial Ministries 211

9.5 Referenda on the Scotland and Wales Acts, 1 March 1979

10.1 Classification and Relative Scale of Local Government Services 234

10.2 Contract Start Dates for 'White Collar' Services 235

10.3 Council Tax Valuation Bands in England 242

11.1 New Organisations in Sub-National Government 259

\section{Figures}

1.1 The Cabinet System 19

1.2 Ministerial Standing Committees of Cabinet 22 


\section{Abbreviations}

\begin{tabular}{|c|c|}
\hline AEU & Amalgamated Engineering Union \\
\hline C\&AG & Comptroller and Auditor General \\
\hline CAP & Common Agricultural Policy \\
\hline CCLGF & $\begin{array}{l}\text { Consultative Council on Local Government } \\
\text { Finance }\end{array}$ \\
\hline $\mathrm{CCP}$ & Common Commercial Policy \\
\hline CCT & Compulsory Competitive Tendering \\
\hline CFSP & Common Foreign and Security Policy \\
\hline CIPFA & $\begin{array}{l}\text { Chartered Institute of Public Finance and Account- } \\
\text { ancy }\end{array}$ \\
\hline COHSE & Confederation of Health Service Employees \\
\hline COSLA & Convention of Scottish Local Authorities \\
\hline CPRS & Central Policy Review Staff \\
\hline CSA & Campaign for a Scottish Assembly \\
\hline DoE & Department of the Environment \\
\hline DUP & Democratic Unionist Party \\
\hline $\mathrm{EC}$ & European Community \\
\hline $\mathrm{EEC}$ & European Economic Community \\
\hline EETPU & $\begin{array}{l}\text { Electrical, Electronic, Telecommunication and } \\
\text { Plumbing Union }\end{array}$ \\
\hline EMU & European Monetary Union \\
\hline EPU & European Political Cooperation \\
\hline ERM & European Exchange Rate Mechanism \\
\hline EU & European Union \\
\hline $\mathrm{FCO}$ & Foreign and Commonwealth Office \\
\hline FDA & First Division Association \\
\hline FMI & Financial Management Initiative \\
\hline GCHQ & Government Communications Headquarters \\
\hline GDP & Gross Domestic Product \\
\hline GLC & Greater London Council \\
\hline GMB & General, Municipal and Boilermakers Union \\
\hline GNP & Gross National Product \\
\hline IEA & Institute of Economic Affairs \\
\hline IGC & Intergovernmental Conference \\
\hline ILEA & Inner London Education Authority \\
\hline
\end{tabular}




$\begin{array}{ll}\text { INLOGOV } & \text { Institute of Local Government Studies } \\ \text { IPPR } & \text { Institute for Public Policy Research } \\ \text { MAFF } & \text { Ministry of Agriculture, Fisheries and Food } \\ \text { MEP } & \text { Member of the European Parliament } \\ \text { MINIS } & \text { Management Information System for Ministers } \\ \text { NALGO } & \text { National Association of Local Government Officers } \\ \text { NAO } & \text { National Audit Office } \\ \text { NEC } & \text { National Executive Committee of the Labour Party } \\ \text { NFU } & \text { National Farmers Union } \\ \text { NHS } & \text { National Health Service } \\ \text { NICS } & \text { Northern Ireland Civil Service } \\ \text { NIDs } & \text { Northern Ireland Departments } \\ \text { NIHE } & \text { Northern Ireland Housing Executive } \\ \text { NIO } & \text { Northern Ireland Office } \\ \text { NUPE } & \text { National Union of Public Employees } \\ \text { OFGAS } & \text { Office of Gas Supply } \\ \text { OFTEL } & \text { Office of Telecommunications } \\ \text { OFWAT } & \text { Office of Water Services } \\ \text { OMCS } & \text { Office of the Minister for the Civil Service } \\ \text { OMOV } & \text { One Member, One Vote } \\ \text { OPSS } & \text { Office of Public Service and Science } \\ \text { OUP } & \text { Official Unionist Party } \\ \text { PAC } & \text { Public Accounts Committee } \\ \text { PLP } & \text { Parliamentary Labour Party } \\ \text { SDA } & \text { Scottish Development Agency } \\ \text { SDLP } & \text { Social Democratic and Labour Party } \\ \text { SDP } & \text { Social Democratic Party } \\ \text { SEA } & \text { Single European Act } \\ \text { SNG } & \text { Sub-National Government } \\ \text { SNP } & \text { Scottish National Party } \\ \text { SO } & \text { Scottish Office } \\ \text { SSA } & \text { Standard Spending Assessment } \\ \text { STUC } & \text { Scottish Trade Union Congress } \\ \text { TECs } & \text { Training and Enterprise Councils } \\ \text { TUC } & \text { Trade Union Congress } \\ \text { UDCs } & \text { Urban Development Corporations } \\ \text { UKREP } & \text { United Kingdom Permanent Representative in } \\ & \text { Brussels } \\ \text { WDA } & \text { Welsh Development Agency } \\ \text { WO } & \text { Welsh Office } \\ & \end{array}$




\section{Notes on the Contributors}

Martin Burch is Senior Lecturer in Government at the University of Manchester. He is joint author of Public Policy in Britain and has also published books and articles on British, Welsh and Australian politics. He is currently completing a book on British Cabinet politics.

Tony Butcher is Lecturer in Government in the Department of Social Policy and Politics at Goldsmiths' College, University of London. He is co-author of The Civil Service Today author of Delivering Welfare, and has written various articles on public administration and policy studies.

Clive Gray is Senior Lecturer in the Department of Public Policy and Managerial Studies at De Montfort University, Leicester. $\mathrm{He}$ has published widely on local and regional government and is author of Government Beyond the Centre. He is currently researching changing patterns in the fields of inner cities and cultural policy in Britain.

Stephen Ingle is Professor and Head of Department of Politics at the University of Stirling. He has worked in the area of British party politics for a number of years and is the author of The British Party System. He is also interested in politics and literature, and his book, George Orwell: A Political Life, was published in 1994.

Roger Levy is Professor and Head of School in the School of Public Administration and Law at the Robert Gordon University, Aberdeen. He is author of Scottish Nationalism at the Crossroads, as well as numerous articles on Scottish government and politics. His current research interests also include the control and management of the EU budget.

Kenneth Newton is a Professor in the Department of Government at the University of Essex and Executive Director of the 
European Consortium for Political Research. He has written widely on urban and comparative politics, public opinion and the mass media

Philip Norton is Professor of Government, and Director of the Centre for Legislative Studies, at the University of Hull. He is the author of numerous books, including The Commons in Perspective, The Constitution in Flux, The British Polity and Does Parliament Matter?. He is co-author of Back From Westminster, joint author of Politics UK, and joint editor of Parliamentary Questions. He is President of the Politics Association.

Robert Pyper is Senior Lecturer in Public Administration at Glasgow Caledonian University . He is author of The Evolving Civil Service and The British Civil Service, joint editor of Britain's Changing Party System, and he has written numerous articles on aspects of UK Government.

Lynton Robins is Coordinator of Public Administration at De Montfort University. He is co-author of Contemporary British Politics and joint editor of Public Policy under the Conservatives, Britain's Changing Party System and Two Decades in British Politics.

Michael Rush is Professor of Politics at the University of Exeter. $\mathrm{He}$ is the author of The Selection of Parliamentary Candidates, Parliament and the Public, Parliamentary Government in Britain and the Cabinet and Policy Formation, and co-author of The $M P$ and His Information. He is co-editor of The House of Commons: Services and Facilities, and editor of Parliament and Pressure Politics. He is also the author of two textbooks on political sociology, and his research interests span British and Canadian politics.

Trevor Salmon is Jean Monnet Professor of European Integration Studies in the Department of International Relations at the University of St Andrews. He is the author of Unneutral Ireland, co-author of Understanding the European Communities and Understanding the New European Community, and co-editor of 
xvi Notes on the Contributors

International Security in the Modern World. He is also the author of numerous articles on the European Union and European security matters.

Kevin Theakston is Lecturer in Politics at the University of Leeds. $\mathrm{He}$ is the author of Junior Ministers in British Government, The Labour Party and Whitehall and The Civil Service since 1945.

David Wilson is Professor of Public Administration and Head of the Department of Public Policy and Managerial Studies at De Montfort University, Leicester. He has written widely in a range of journals. He is co-author of Public Administration in Britain Today and Local Government in the United Kingdom. 


\section{Preface}

The original idea for a book surveying the governing institutions of the United Kingdom in the 1990s stemmed from our work on Talking Politics, the journal of the Politics Association. Many of the contributors to this volume had authored short articles for the journal, examining aspects of UK government, and we believed there was scope for these to be expanded, updated and moulded into a self-contained text.

We were encouraged when our publisher, Steven Kennedy took a serious interest in this project and helped us to steer it towards publication. We are grateful to him for his patience and perseverance throughout. Additional thanks are due to Ian Holliday, from the University of Manchester, who read the initial typescript and made a number of useful suggestions for improvement. Naturally, we add the conventional rider that the final responsibility for the text rests with us, and we hereby absolve others from blame for any weaknesses or errors!

Finally, we would like to thank all of our contributing authors for cooperating with our schedules, deadlines and general thematic requirements.

ROBERT PyPER

LYNTON ROBINS 


\section{Acknowledgements}

The publishers and editors would like to thank the Study of Parliament Group and the Joseph Rowntree Foundation for permission to use data contained in Table 5.4 and Table 10.1, respectively. 